\title{
Civic Education as a Means to Build Social Care Characters for Students with Disabilities
}

\author{
Muhammad Rochmat Alashary,", Dadang Sundawa ${ }^{2}$ \\ ${ }^{1,2}$ Universitas Pendidikan Indonesia Bandung, Indonesia \\ *Corresponding author.Email: muhammadrochmatalashary@upi.edu
}

\begin{abstract}
Education for children with special needs or persons with disabilities is indeed very important, because it supports their belief in attending education levels according to the level of intelligence they have. As for the instrument regarding education guarantee for all groups without exception, in fact it has become a joint commitment of all nations to fight for the basic rights of every child in obtaining education. By integrating into the same classroom, it is hoped that it will provide understanding to other students that in life there will be many differences. As stipulated in the law, persons with disabilities have the right to get proper education without discrimination or interference from other parties in undergoing education, especially at school. Because educational institutions have integrated students with disabilities into regular classes at every level, and they must not look at the backgrounds of their students in providing educational services; both from academic intellectual ability, physical condition, as well as mentality and emotions. And the existence of these differences should not be used as an obstacle, but a fact that must be respected and respected. The conditions and situations of diverse learning like this can be a very effective medium for character building for every student. A sense of empathy, sympathy, tolerance, and care will appear in this educational concept. However, in practice sometimes there is still discrimination and lopsided views towards persons with disabilities. Therefore, as an educator, especially civic education, has a role in providing an understanding of applicable laws and regulations, as well as rights and obligations as citizens through education that can form smart and good idealship indiscriminately. This study used a qualitative design with a case study method. The data obtained in this study are the efforts and obstacles of the school in building social care character through civic education. So that it is reflected in the life of school learning activities that there are no students with disabilities who getor bullying.
\end{abstract}

Keywords: Discrimination, Persons with Disabilities, Social Care Character.

\section{INTRODUCTION}

Civic education is defined as a science that can support citizens to participate in the life of the nation and state. This is very much in line with the mission of one of the Civics lessons as character education. In character education, an understanding process is needed that refers to the cultivation of values and habituation so that students can consciously carry out good behavior. Character is formed by habits that are carried out every day, therefore if the teacher's attitude in teaching will affect the character of students. In addition to the above, Civics has an important role in developing character through the teacher's role in teaching civic education. Between character education and citizenship education, both can build good character. One of them is the social care character that can be applied to inclusive schools by getting normal children to mix and have good social relationships every day with other students with disabilities.
The attitude of social caring character is indeed needed to grow in each individual because at this time a sense of social indifference towards other humans is increasingly visible and is the reason why this character needs to be grown in each individual. This is intended so that character education in the community can be realized and instill good social care values. This education can be obtained from education in the family, community and school environment, including inclusive schools, as well as students with disabilities. In this case, the social care character that is formed starts from the school environment and the surrounding atmosphere. Humans are creatures whose nature requires other creatures as well or in other terms social beings who interact in their lives in harmony. [1] says that social care is a process that exists between attitudes and feelings that make a person able to get used to his environment and comes from within himself. The picture of the success of a person's social adjustment is said to be successful if he has carried out social adjustments well and can blend in with the community 
and be accepted to join in exploring a new area, this also applies to people with disabilities.

\section{THEORETICAL REVIEW}

\section{A. Civic Education}

Civic Education is one of the fields of study that carries out a national mission to educate the life of the Indonesian nation through the corridor of value-based education. Civic education carries the main objective of developing "civic competences" namely civic knowledge, civic disposition (civic values, and attitudes of citizenship), and civic skills (a set of intellectual, social, and personal citizenship skills) which should be mastered by each individual citizen [6]. These three components conceptually and theoretically since 1994 have been proposed by the Center for Civic Education in the National Standards for Civics and Government [7].

\section{B. Social Care Character}

The purpose of character education is to be able to shape and develop children's character so that they are able to create students who believe in the one and only God, become just and civilized human beings, have the spirit of Indonesian unity, have a populist spirit led by wisdom in judicial deliberation, and are able to uphold social justice for all. all Indonesian .[4]

According to Talema says that empathy is defined as a person's compassion for the feelings of others. Kohlberg defines empathy as a process by which a person feels the influence of others regarding what he feels.[4] The emergence of a sense of empathy in humans will foster a sense of caring for others, this is not meant to interfere or want to know other people's affairs but helps to be able to solve the problems at hand. According to the Ministry of National Education, a sense of social care is an attitude expressed to others in helping when needed. In another explanation, it is explained that social care is reaching out for help in the form of attitudes and actions.[5] So social care is an attitude that is formed because of communication with compassion and empathy and has a desire to always lend a hand in helping others.

\section{METHOD}

This research was conducted through a qualitative approach, with a case study method. This study aims to determine the efforts made by inclusive schools in building the social care character of their students towards other students with disabilities so that they can study together without any cases of bullying and discrimination. The source of this research was obtained from the initial research conducted by the author to one of the private inclusive elementary schools in the city of Bandung. Data analysis in this research, using techniques from Nawawi a case study data that can be obtained through research from several related source.[6]

\section{RESULTS AND DISCUSSION}

A. Result

The research process on character building social care for students with disabilities at Primary School Binar Indonesia was carried out remotely in connection with learning carried out during the Covid-19 pandemic. From the results of interviews with the school, it was stated that the development of social care character in the school was built through various efforts, such as: Integration into teaching and learning activities, especially in civic education subjects, habituation in daily life in the educational unit, integration into extracurricular activities, the application of habituation in everyday life at home which is in line with those at school.

\section{B. Discussion \\ 1. The Importance of Social Awareness}

Currently, the development of the era in Indonesia is strongly influenced by the existence of globalization. This term is not foreign anymore because its influence brings a positive impact to an unfavorable impact. Examples include the loss of a sense of caring formed in the community. Here are some examples that show the loss of social awareness, including:

- Not ready to help when there is help, nowadays most people are busy recording rather than helping

- Social carelessness shown to neighbors, such as not helping when there is gotong royong or community service

- Not participating in social activities

Buchari Alma, et al explained the causes of the decreased sense of social care due to technological advances including: [7]:

- Internet technology

- The Internet is a very wide and transparent virtual world in finding information. Humans lose track of time because they are too busy exploring the world. Without realizing it, humans forget and ignore the condition of the surrounding community, so that their sense of caring for the surrounding environment is defeated by the individualism formed from these activities.

- Technology that supports facilities as entertainment

- The development of today's era is growing due to increasingly sophisticated technology, thus making children in particular less interact with other people. Victims of advanced technology make children even more lazy, although not all children are like that, but nowadays the situation shows that sophisticated devices make it easy to access all applications, be it games or social media, which are easy to get and enjoy. So the interactions that occur in the community will 
certainly be affected, especially the longer one's social care will decrease and fade.

- Television viewing technology

- Currently television is a medium that is everywhere and easy to access, not as difficult as in the past. Information provided from television media is currently unfortunately still a lot of negative things that are broadcast. Such as shows that are less educative for children, ranging from advertisements, soap operas and films that are still not suitable for viewing for children and need parental supervision. Although not all information shown on television is negative, there are positive things that are broadcast that are able to educate but are now rare. The impact on children with frequent or mostly watching television makes children more lazy, also becomes less social in their friend's environment because they are more interested in watching than playing with their peers so that socialization among friends is reduced and creates a sense of lack of care

- Incoming Western Cultural Technology

- Western culture that entered Indonesia made people change their lifestyle to become individualists like urban communities. When viewed, the culture of the ancient Indonesian people was very closely prioritizing mutual cooperation and cooperation. However, at this time due to the influence of the entry of western culture, so that people become less sensitive or less concerned about their social environment.

\section{Implementation Strategy of Social Care Character Education}

Character education in schools can be carried out through intracurricular and extracurricular activities. In its implementation, it consists of several activities that can be carried out by students including: (1) carried out in teaching and learning activities (KBM), (2) implemented and implemented in life, (3) carried out in extracurricular activities, and (4) getting used to applying in daily life in harmony with the education unit. There are several integration models as follows:

a. Integration for self-development through:

- School activity

- Habits at school such as interacting with friends $\&$ teachers, greeting each other, greeting, shaking hands, and holding infaq or sodaqoh.

- Impromptu activities

- This activity is usually done when the teacher corrects students' mistakes. For example, reprimanding children who scribble on the study table, who fights, who are not conducive in the classroom, and so on.

- Exemplary students

- An exemplary attitude is a commendable behavior that must be shown from a teacher who exemplifies good deeds in school life. For example, when speaking politely, acting well, helping each other, paying attention, and so on.

- Conditioning

- In order for the implementation of character education in schools to be realized, schools must condition activities that reflect the culture and character of the Indonesian nation. For example, trash cans are provided in several places and are always cleaned, teaching tools or materials are neat and orderly, and toilets are always clean

\section{b. Integration through school culture}

Culture is one of the characters, character, and image of the school in the view of the wider community. The atmosphere of school life is a place for students, teachers, and other educators to interact with one another. The value of character education carried out in activities is beneficial for students by utilizing school facilities.

In addition, the condition of the school environment, including the student's own response to other students, greatly influences the development of socially caring characters, as shown Stephen Covey, there are four responses to diversity, namely the highest level of celebration, the second is respect, then acceptance, and the lowest is tolerance. When correlated, normal students at Binar Indonesia's inclusive schools have placed themselves at a good response level, by accepting and respecting other students with disabilities. It is also hoped that they can go to the highest level, namely celebration, by collaborating or working together to produce something created by combining regular students with students with disabilities.[8]

\section{CONCLUSION}

The results of research on the development of social care characters for students with disabilities at the Binar Indonesia primary school was carried out remotely in connection with learning carried out during the Covid-19 pandemic. From the results of interviews with the school, it was stated that the development of social care character in the school was built through various efforts, such as: Integration into teaching and learning activities, especially in civic education subjects, habituation in daily life in the educational unit, integration into extracurricular activities, the application of habituation in everyday life at home which is in line with those at school.

\section{ACKNOWLEDGMENTS}

The research is a grant from the Indonesia University of Education. The author would like to express sincere appreciation for all the support provided. 


\section{REFERENCES}

[1] E.B. Hurlock, Psikologi Perkembangan: Suatu Pendekatan dalam Suatu Rentang Kehidupan. Jakarta: Erlangga, 1990.

[2] U.S. Winataputra, Jatidiri Pendidikan Kewarganegaraan Sebagai Wahana Pendidikan Demokrasi. Disertasi Program Pascasarjana UPI: tidak diterbitkan, 2001.

[3] M.S. Branson, Making the Case for Civic Education: Where We Stand at the End of the 20th Century. Washington: CCE, 1999.
[4] Z.D. Zuhcdi and M.S. Masruri, Model pendidikan : Terintegrasi dalam Pembelajaran dan Pengembangan Kultur Sekolah. Yogyakarta : UNY Press, 2012.

[5] Ministry of Education, New Zealand, 2010.

[6] H. Nawawi, Metode Penelitian Bidang Sosial. Yogyakarta: Gadjah Mada Univercity Press. 2003.

[7] A. Buchari, Pembelajaran Studi Sosial. Bandung : Alfabeta, 2010

[8] S.R. Covey, The 7 Habits Of Highly Effective People. Newyork : Simon \& Schuster. 1989. 